\title{
Energy consumption of a passenger car with a hybrid powertrain in real traffic conditions
}

ARTICLE INFO

Received: 21 July 2021

Revised: 31 August 2021

Accepted: 23 September 2021

Available online: 5 December 2021
The analysis of energy consumption in a hybrid drive system of a passenger car in real road conditions is an important factor determining its operational indicators. The article presents energy consumption analysis of a car equipped with an advanced Plug-in Hybrid Electric Drive (PHEV), driving in real road conditions on a test section of about $51 \mathrm{~km}$ covered in various environmental conditions and seasons. Particular attention was paid to the energy consumption resulting from the cooperation of two independent drive units, analyzed in terms of the total energy expenditure. The energy consumption obtained from fuel and energy collected from the car's batteries for each run over the total distance of $12500 \mathrm{~km}$ was summarized. The instantaneous values of energy consumption for the hybrid drive per kilometer of distance traveled in car's real operating conditions range from 0.6 to $1.4 \mathrm{MJ} / \mathrm{km}$, with lower values relating to the vehicle operation only with electric drive. The upper range applies to the internal combustion engine, which increases not only the energy expenditure in the TTW (Tank-to-Wheel) system, but also $\mathrm{CO}_{2}$ emissions to the environment. Based on the experimental data, the curves of total energy consumption per kilometer of the road section traveled were determined, showing a close correlation with the actual operating conditions. Obtained values were compared with homologation data from the WLTP test of the tested passenger car, where the average value of energy demand is $1.1 \mathrm{MJ} / \mathrm{km}$ and the $\mathrm{CO}_{2}$ emission is $23 \mathrm{~g} / \mathrm{km}$.

Key words: energy consumption, hybrid vehicle, road tests, energy consumption analysis

This is an open access article under the CC BY license (http://creativecommons.org/licenses/BY/4.0/)

\section{Introduction}

The global economy growth, and hence the development of society and its mobility, forces to introduce innovation to broadly understood means of transport, such as road and off-road vehicles, water and air vehicles. However, regardless of the type of means of transport, the requirements for limiting the amount of harmful substances emitted by them in exhaust gases are increasing, as well as strict limits on $\mathrm{CO}_{2}$ emissions. The current limits of carbon dioxide $\mathrm{CO}_{2}$ emissions forces to look for various technical solutions to meet these requirements, for example, to drive unit hybridization or search for its new type. The drive unit in a hybrid car is a combination of a modern internal combustion engine (ICE) and an electric motor (EM), thanks to which the car is equipped with two independent energy storage. The issues of replacing the car power unit evoke a lot of emotions and are the subject of many analyzes by specialists on different continents. In this matter, the "game" is high, because the introduction of even stricter emission limits for the year 2030 forces manufacturers to spend significant amounts on production or new technologies development for powering internal combustion engines. The introduction of new technologies is connected with the need to accept the driver as a user of such a vehicle. It is about obtaining satisfactory results of using the car in relation to economy, ecology, dynamics, and operating costs. Hence, the search for such technological solutions that allow to obtain satisfactory results in each of the above-mentioned areas is extremely difficult. The importance of each area is significant factor in car swapping, as outlined in Arthur D Little's report, The Future of Automotive Mobility. The report presents the preferences of car users based on several most important factors taken into account when buying cars as shown in Table 1 [7].

Table 1. Car preferences of users taken into account when buying a car, in \% response to factor

\begin{tabular}{|l|c|c|c|c|}
\hline \multirow{2}{*}{ Country } & \multicolumn{4}{|c|}{ The most important factors \% } \\
\cline { 2 - 5 } & $\begin{array}{c}\text { Purchase } \\
\text { price }\end{array}$ & Environment & $\mathrm{CO}_{2}$ emission & $\begin{array}{c}\text { Economy - total } \\
\text { cost of ownership } \\
\text { (TCO) }\end{array}$ \\
\hline China & 32 & 51 & 48 & 40 \\
\hline $\begin{array}{l}\text { European } \\
\text { Union }\end{array}$ & 43 & 32 & 35 & 28 \\
\hline USA & 35 & 28 & 29 & 32 \\
\hline
\end{tabular}

These preferences show large differences among car users for individual countries. For example, in the USA, priority is given to the purchase price and operating costs. In Europe, however, less attention is paid to operating costs, as opposed to China, where environmental and operating costs are the most important.

New technologies implemented on cars are considered in several areas where a thorough analysis should be carried out:

- ecology - new materials and technology require new raw materials for production. At the same time, the new technology requires other energy sources to power drive units. The cost of energy carriers is high - for example, when obtaining hydrogen.

- economy - not only the costs of implementing the technology or production are considered, but also those related to the total operating costs of a given car. Not only current operating costs in the form of fuel/energy, but also purchase or maintenance and repair costs are taken 
into account here [8]. The issue of reselling a car on secondary market is not without significance here.

- social - related to the acceptance of new technology, such as the mobility of new cars, understood as the ability to cover longer routes, the availability of infrastructure that allows to replenish energy storage in a short time. Time is essential, especially in a society that is constantly lacking it.

- legal - related to approval regulations, emission limits of individual components in exhaust gases or presence of certain elements in automotive parts, the issue of carbon footprint or taxes. The matter of recycling materials is also important.

- technological - at present, the challenge is the easiest to meet, due to the theoretical lack of limitations.

Currently, it seems that the natural successor to changing car market is the transformation from powertrain ICEV (Internal Combustion Engine Vehicle) to BEV (Battery Electric Vehicle). The electric drive has limitations in terms of mobility, infrastructure and density of energy stored in batteries and their mass. For this reason full hybrid cars are a good bridge to the transition from ICEV to BEV systems. The article focuses on car energy consumption indicators with a powertrain PHEV at different times of the year over total distance of $12500 \mathrm{~km}$. The car was operated in real traffic conditions from new products, i.e. from zero mileage in 2021. Energy consumption in the propulsion system is analyzed in terms of TTW (Tank to Wheels), which is the sum of total energy expenditure obtained from the storage in relation to the distance covered. These results were compared with the WLTP (The Worldwide Harmonized Light Vehicles Test Procedure) homologation test data.

\section{Motion energy consumption}

Many authors have analyzed motion energy consumption, drive efficiency and other properties of various drive system configurations. Ahman et al. [1] conducted a comparison of the average efficiency of classic ICEV systems and alternative BEV, HEV, FCEV systems. The obtained primary efficiencies ranged from $19 \%$ for ICEV to $31 \%$ for $\mathrm{BEV}$. In the case of using renewable energy, the primary efficiencies was estimated as $57 \%$ for BEV and $26 \%$ for FCEV. However, it was noted that there is a potential for further optimization of the discussed systems and obtaining maximum efficiencies of $45 \%$ for ICEV and up to $76 \%$ for other types of drives. Sharer et al. [22] analyzed the demand for energy and the efficiency of ICEV and HEV in selected driving cycles. As shown by the tests, the efficiency of the drive systems was determined in the range of 18 $27 \%$ for ICEV and 34-37\% for HEV, depending on the compared driving cycle.

Some researchers made the energy requirements of various drive systems dependent on the preferred driving style. On the other hand Thomas et al. [23] checked the energy demand for ICEV and HEV in driving cycles using a cycle intensity index in the range 0.8 to 1.1 . The obtained results indicate that an aggressive driving style simulated by an increase in the cycle intensity index causes an increase in energy consumption by about $74 \%$ for ICEV and as much as $105 \%$ for $\mathrm{HEV}$.
Pitanuwat and Sripakagorn [20] conducted similar studies, but carried out in real conditions, comparing the energy consumption for a statistically normal driving style to the energy consumption of very aggressive driving. The increase in consumption was achieved for an aggressive driving style in the range of $80-113.8 \%$ for ICEV to $102.5-$ $220 \%$ for HEV. Orecchinii at al. [17] compared the fuel consumption of ICEV and HEV vehicles in real driving conditions, stating that $\mathrm{HEV}$ s maintain fuel consumption in the range of $3.5-5.5 \mathrm{dm}^{3} / 100 \mathrm{~km}$ at average driving speeds in the range of $20-100 \mathrm{~km} / \mathrm{h}$. In turn, ICEV systems generate the highest fuel consumption at low average driving speeds resulting from driving in the city with high traffic density, up to $13.5 \mathrm{dm}^{3} / 100 \mathrm{~km}$. In the case of ICEV, you can also see a minimum fuel consumption of approx. $4 \mathrm{dm}^{3} / 100 \mathrm{~km}$ at average speeds of $70-80 \mathrm{~km} / \mathrm{h}$, and then an increase in fuel consumption to approx. $5.5 \mathrm{dm}^{3} / 100 \mathrm{~km}$ at average speeds of $100 \mathrm{~km} / \mathrm{h}$ is observed. Wang et al. [24, 25] compared fuel and energy consumption in selected 7 driving cycles for ICEV, HEV and BEV. The fuel consumption was in the range of $6.37-14.85 \mathrm{dm}^{3} / 100 \mathrm{~km}$ for the ICEV, $4.51-5.84 \mathrm{dm}^{3} / 100 \mathrm{~km}$ for the HEV and electricity consumption of $16.43-20.12 \mathrm{kWh} / 100 \mathrm{~km}$. The recorded fuel consumption was also compared for real traffic conditions in Beijing. Electricity consumption BEV was converted to the equivalent of the consumed fuel. The obtained values are respectively $12.5 \mathrm{dm}^{3} / 100 \mathrm{~km}$ for ICEV, $5.5 \mathrm{dm}^{3} / 100 \mathrm{~km}$ for HEV and $2.0 \mathrm{dm}^{3} / 100 \mathrm{~km}$ for BEV.

Wenwei et al. [11] compared well-to-wheel energy consumption for different drivetrains. At the counting, the equivalent of fossil energy consumptions was assumed, with values from $3.4 \mathrm{MJ} \cdot \mathrm{km}^{-1}$ for ICEV to $2.0 \mathrm{MJ} \cdot \mathrm{km}^{-1}$ PHEV. For HEV were characterized by slightly higher energy of about $2.2 \mathrm{MJ} \cdot \mathrm{km}^{-1}$ and BEV of $2.5 \mathrm{MJ} \cdot \mathrm{km}^{-1}$. The results of measurements for urban driving in real conditions were also presented, obtaining $9.1 \mathrm{dm}^{3} / 100 \mathrm{~km}$ for ICEV and $17 \mathrm{kWh} / 100 \mathrm{~km}$ for BEV at the same time. The quoted comparison of fuel consumption and electricity consumption are calculated in different units, therefore they should be expressed in $\mathrm{MJ} / \mathrm{km}$.

The car motion can be analyzed regarding consequences of specific energy changes taking place in its drive system. It should be noted that currently the dominant technical solution for most powertrain is combination of the ICE with the drive train, forming a monoblock, most often installed on car's front axle. In energy balance of the entire moving car, by following the set speed profile, energy produced from burned fuel $\mathrm{E}_{\mathrm{T}}$ is spent on its drive, but also on additional devices' drive and losses resulting from energy conversion and drive transmission to vehicle wheels. Thus, according to equation (1), it is the sum of: the energy supplied to wheels by drive system and defined as the motion energy consumption $\left(\mathrm{E}_{\mathrm{M}}\right)$ needed to overcome the resistance of vehicle motion, energy losses of drive unit $\left(\Delta E_{E}\right)$ and energy losses of drive train $\left(\Delta \mathrm{E}_{\mathrm{D}}\right)$, as well as losses of energy supplied to drive system without transmitting to drive wheels $\left(\Delta \mathrm{E}_{\mathrm{L}}\right)$, i.a. car standstill phase:

$$
\mathrm{E}_{\mathrm{T}}=\mathrm{E}_{\mathrm{M}}+\Delta \mathrm{E}_{\mathrm{E}}+\Delta \mathrm{E}_{\mathrm{D}}+\Delta \mathrm{E}_{\mathrm{L}}
$$


All components of car energy balance vary over time and depend on speed profile parameters, and environmental conditions. For a simple car speed profile consisting of four car phases (accelerated motion, steady motion - constant speed, deceleration, and stop), the energy expenditure is calculated from start to stop, and car kinetic energy at the beginning and end is zero. The basic values of speed profile parameters, expressed as average speed $\bar{V}$, path length $L$ or average acceleration $\overline{\mathrm{a}}$, depend on participation of individual profile phases on a given road section. In practice, the presence of a simple speed profile is not common. In fact, there are complex speed profiles, where the kinematic profile parameters (speed, acceleration) are the average of many components of simple profiles (simple modules). The average speed of complex profile can be calculated from the dependence:

$$
\bar{V}=\frac{\sum_{i} L}{\sum_{i} \int_{t_{s}}^{t_{e} \frac{d v}{a}}+\sum_{i} \frac{L_{c}}{V_{c}}+\sum_{i} \int_{t_{s}}^{t_{e}} \frac{d v}{a_{D}}+\sum_{i} T_{L}}
$$

Standstill is an undesirable phase of movement, because at this time, during operation of internal combustion engine, energy is generated from burned fuel, which is not received by the drive train.

In the authors' own work [9], attention was paid to the differentiated fuel demand of a car moving in real traffic conditions resulting from different dynamics of its acceleration. In road tests, significant discrepancies in mileage fuel consumption were found, ranging from 12.44 to 31.8 $\mathrm{dm}^{3} / 100 \mathrm{~km}$, recorded over the distance of $1 / 4$ mile, depending on the acceleration dynamics and gear selection in the driveline. Choosing a gear ratio with lower values resulted in a reduction in fuel consumption, with average efficiency of drive system ranging from 19.38 to $24.6 \%$. The values shown above are registered for an ICEV car with an internal combustion engine built according to the downsizing philosophy.

In own work, the authors [4] analyzed the impact of various drive transmission systems, paying attention to AT and MT transmissions, for which maximum efficiency points were established at a speed of $70 \mathrm{~km} / \mathrm{h}$, amounting to $24 \%$. However, regardless of the study and analysis of the car's motion phases, the issue of fuel consumption is a key point from the car's economy point of view. An important issue is the possibility of reducing fuel consumption by recovering car kinetic energy in its retarded motion phase, where in most cases energy is dissipated by the braking system to the environment. Hence, the introduction of Hybrid Electric Vehicle (HEV), was aimed at reducing the loss of energy in the drive system through its energy recovery $[16,21,26]$. In such cars, there is an integrated hybrid drive system with two energy storages (fuel and electricity), as well as two independent drive units (combustion and electric), which drive the vehicle together.

\section{Hybrid drive system of a passenger car}

It is predicted that over the next 30 years, the number of new cars produced in the world will increase by nearly $30 \%$, which will result in over 2 billion cars driving on the world's roads in several dozen years $[3,10]$. New cars will be equipped with advanced powertrains and this is due to the introduction of new, increasingly stringent emission standards and carbon dioxide into the atmosphere. Many countries plan to ban the registration of new cars powered only by an ICE (Table 2).

Table 2. Planned restrictions on the possibility of registering new cars

\begin{tabular}{|l|c|}
\hline Country & $\begin{array}{c}\text { Scheduled year for banning the } \\
\text { ICEV }\end{array}$ \\
\hline Netherlands & 2025 \\
\hline India & 2030 \\
\hline France & 2040 \\
\hline Germany & 2040 \\
\hline Spain & 2040 \\
\hline United Kingdom & 2040 \\
\hline
\end{tabular}

In 2025 in the European Union, the introduction of a new exhaust emission standard called Euro 7 is announced, but fulfilment of new emission limits based only on the internal combustion engine will be very difficult or even impossible, while maintaining high values of vehicle traction parameters related to dynamics and achieving average speed of travel [14]. From the driver's point of view, the use of different drive units is not significant in the light of the requirements for a car designed to transport people and goods in a sufficiently short time on a given road section. Hence, hybrid drive systems have been dominated by known drive units, most often connected in a parallel manner (Fig. 1).

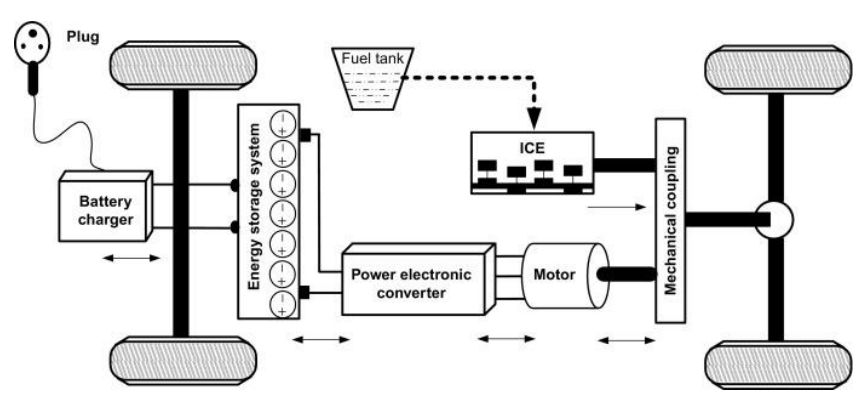

Fig. 1. Architecture of the parallel hybrid electric vehicle [7]

It results from the greater versatility of such a drive system solution in everyday use, both in urban and extra-urban traffic $[2,5,18,19]$. Many authors conduct research on this type of hybrid drive systems in relation to the emission limits of harmful components $[15,16]$ as well as in terms of total energy consumption in normal operating conditions $[12,13,20]$ or in relation only to the electric drive system $[6,19]$. The real test that verifies such hybrid drive systems in terms of energy consumption is road measurements under real operating conditions. Therefore, as part of this study, the impact of road conditions on the car's mileage consumption was analyzed.

\section{Methodology and course of own research}

The difference in energy value of energy carriers stored in passenger cars with hybrid drive systems cause that a direct comparison of the mileage consumption for an internal combustion engine with the mileage consumption for an electric motor is not adequate in terms of units used. The use of converted mileage energy consumption in a standardized energy (SI system) measurement unit $\mathbf{J}$ per 
kilometer of distance traveled in relation to both drive units allows for increasing the possibility of comparing them as to their operation time within the drive system, total energy expenditure or the possibility of comparing the values obtained in operational tests to the values obtained in homologation test. Hence, the measurements were carried out with the car in real traffic conditions, at different times of the year, in relation to normal operating conditions resulting from everyday use of the car. It is not a reference to the RDE cycle where the driving cycle is divided into urban, extra-urban and motorway driving. However, the results of the measurements are related to the values recorded in the homologation of the Euro 6d car.

\subsection{Mileage energy consumption}

Mileage energy consumption is a measure of the energy expended from the storage of the car's propulsion units per kilometer of the distance traveled. Taking into account the internal combustion engine, the total energy $\left(\mathrm{E}_{\mathrm{Tf}}\right)$ spent on driving a car depends on the product of amount of fuel consumed (VFC) and its calorific value $\left(\mathrm{W}_{\mathrm{O}}\right)$, which can be presented by the equation:

$$
\mathrm{E}_{\mathrm{Tf}}=\mathrm{W}_{\mathrm{o}} \cdot \int_{\mathrm{t}_{\mathrm{s}}}^{\mathrm{t}_{\mathrm{e}}} \mathrm{FC} \mathrm{dt}
$$

where: VFC - vehicle fuel consumption, $\mathrm{g} / \mathrm{s}, \mathrm{W}_{\mathrm{o}}-$ fuel calorific value, depending on its type (gasoline, diesel, etc.), $\mathrm{J} / \mathrm{kg}, \mathrm{t}_{\mathrm{s}, \mathrm{e}}-$ start and end time of energy calculation, $\mathrm{s}$.

For an electric drive unit, the total energy $\left(\mathrm{E}_{\mathrm{Te}}\right)$ expended on the drive depends on the electric motor construction and the method of supplying with direct or alternating current and also the instantaneous power supplied from batteries to electric drive unit. For alternating current, the total energy can be calculated from equation (4):

$$
\mathrm{E}_{\mathrm{Te}}=\int_{\mathrm{t}_{\mathrm{s}}}^{\mathrm{t}_{\mathrm{e}}} \mathrm{Pdt}
$$

where: $\mathrm{P}$ - electric power, $(\mathrm{W})$, for AC motors, the electric power is the product of $P=U(t) I(t) \cos \varphi(t)$, where $U-$ electric voltage over time, I - electric current intensity over time, $\cos \varphi$ - ratio of active to apparent power over time, $t_{\mathrm{s}, \mathrm{e}}$ - start and end time of power consumption.

The total energy supplied to car's propulsion system is the sum of equations (3) and (4) and is equal to the energy drawn from various energy stores over time. In hybrid drive systems, it is possible to recover energy in delayed motion during coasting or braking, which, however, is not analyzed in terms of operation, because it replenishes the energy reservoir by recharging the batteries and thus increases the car's range.

The total energy consumed by a car, after conversion to the distance traveled, shows the mileage energy consumption of the car according to the equation (5):

$$
\mathrm{Q}_{\mathrm{PHEV}}=\frac{\mathrm{E}_{\mathrm{T}}}{\mathrm{L}}
$$

The obtained values are varied and depend on used drive unit type and the parameters on a given road distance: average speed, time, and distance.

\subsection{Course of research}

The research concerned the analysis of mileage energy consumption in a passenger car equipped with a Plug-in Hybrid Electric Drive, taking into account:
1. The analysis of working time in the hybrid drive system of individual drive units.

2. The analysis of the car's mileage energy consumption during its operation.

3. The analysis of the ambient temperature influence on car's mileage energy consumption.

The monitoring of traction and energy parameters was carried out using the Mercedes-Benz software, which allowed for an ongoing overview of the following data:

- total range of the drive system,

- range divided by type of drive unit used,

- energy storage capacity,

- total distance traveled,

- distance divided by drive units,

- total travel time,

- travel time divided into drive units,

- average speed as well as energy expenditure as mileage fuel consumption and electricity consumption.

These data were systematically saved in a database and analyzed. The analysis of mileage energy consumption was carried out for the actual car's operating conditions resulting from daily runs on a specific road section. The driver was not subjected to any pressure in terms of driving style. The runs were characterized by free route choice with a length of about $50 \mathrm{~km}$, as well as a random selection of drivers with the standard hybrid drive system control mode. The distance of the route for the test drives resulted from the range of the energy storage, so that the electric drive system was the dominant in the driving range. Before each of the runs, the electric reservoir was filled from the $230 \mathrm{~V}$ electric network using a factory charger up to the SOC indicator's value of $100 \%$. In total, 67 runs were analyzed in detail.

\subsection{Research object}

The study of car's mileage energy consumption with a PHEV hybrid drive system in real operating conditions was

\begin{tabular}{|c|c|}
\hline Producer & Mercedes-Benz \\
\hline Type & A250e/V177 \\
\hline Internal combustion engine displacement & $1332 \mathrm{~cm}^{3}$ \\
\hline Internal combustion engine power & $118 \mathrm{~kW}$ at $5500 \mathrm{rpm}$ \\
\hline $\begin{array}{l}\text { Maximum torque of the internal combus- } \\
\text { tion engine }\end{array}$ & $210 \mathrm{Nm}$ at $1750 \mathrm{rpm}$ \\
\hline Electric motor power & $75 \mathrm{~kW}$ \\
\hline Long - lasting electric motor power & $55 \mathrm{~kW}$ \\
\hline Maximum torque of the electric motor & $450 \mathrm{Nm}$ \\
\hline Installation of the drive unit & At the front, transversely \\
\hline Internal combustion engine supercharging & Turbocharger \\
\hline Drive system type & PHEV \\
\hline Drive train & Automatic -8 gears \\
\hline Vehicle mass & $1817 \mathrm{~kg}$ \\
\hline Emission standard & Euro 6 (AP) \\
\hline Range on gasoline & $450 \mathrm{~km}$ \\
\hline Battery range & $75 \mathrm{~km}$ \\
\hline $\begin{array}{l}\text { Average } \mathrm{CO}_{2} \text { emissions according } \\
\text { to WLTP }\end{array}$ & $\begin{array}{c}23 \mathrm{~g} / \mathrm{km} \\
\left(1.0 \mathrm{dm}^{3} / 100 \mathrm{~km}\right)\end{array}$ \\
\hline Energy consumption for the EV system & $209 \mathrm{Wh} / \mathrm{km}$ \\
\hline Battery capacity (electricity storage) & $15.6 \mathrm{kWh}$ \\
\hline
\end{tabular}
carried out on a Mercedes-Benz A 250e vehicle (Table 3).

Table 3. Parameters of the tested vehicle $[27,28]$ 
It is a passenger car from 2021 with a parallel full hybrid drive system, where two drive units (electric and combustion) are installed on the front drive axle. The power units cooperate with an 8-speed 8 F-DCT (Front-Double Clutch Transmission) gearbox and a drive is transmitted to front wheels.

Table 3 shows the average energy consumption for electric drive train and the average $\mathrm{CO}_{2}$ emissions according to the WLTP test, read from the approval certificate [27]. Attention should be paid to the increase in weight of the test car by nearly $300 \mathrm{~kg}$ in relation to the car with the ICEV internal combustion drive system due to the use of additional components of the EV electric drive system (storage tank, electric motor, inverter and control system).

\section{Research results}

In accordance with the adopted methodology, the car's mileage consumption analysis was carried out for its actual operating conditions in everyday driving for a distance of about $50 \mathrm{~km}$. The test drives occurred in various weather and road conditions. Table 4 shows the traction and energy parameters for analyzed groups of runs, divided by season.

Table 4. Average values of drive system's operating parameters during runs made during the standard operating mode of hybrid drive

\begin{tabular}{|c|c|c|c|c|c|c|c|c|c|c|}
\hline Group & $\underset{\underline{\Xi}}{\bar{g}}$ & 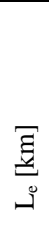 & $\begin{array}{l}\text { 㫪 } \\
\underline{E}\end{array}$ & $\begin{array}{l}\underset{\Xi}{\Xi} \\
\stackrel{\Xi}{z} \\
>\end{array}$ & $\begin{array}{l}\frac{\bar{g}}{8} \\
\dot{8} \\
\Xi \\
\dot{0}\end{array}$ & 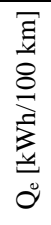 & $\sum_{\bar{E}}^{\bar{g}}$ & $\begin{array}{l}\bar{\Sigma} \\
\dot{\Xi}\end{array}$ & 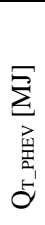 & $\begin{array}{l}\text { ठ } \\
\text {. } \\
\text { ह्चे } \\
\text { - }\end{array}$ \\
\hline $\begin{array}{l}\text { Winter } \\
\text { (I) }\end{array}$ & $\stackrel{\vec{\infty}}{\stackrel{\phi}{+}}$ & oे & $\stackrel{\sim}{\stackrel{P}{n}}$ & $\begin{array}{l}\text { in } \\
\text { in }\end{array}$ & $\vec{\jmath}$ & $\stackrel{2}{a}$ & $\stackrel{\infty}{m}$ & $\underset{\dot{m}}{\stackrel{p}{m}}$ & $\underset{i}{0}$ & $\bar{n}$ \\
\hline $\begin{array}{l}\text { Spring } \\
\text { (II) }\end{array}$ & $\stackrel{\substack{\infty \\
\infty}}{\infty}$ & $\stackrel{m}{f}$ & $\stackrel{\substack{\infty \\
\infty}}{\infty}$ & $\stackrel{\infty}{i}$ & $\stackrel{1}{\div}$ & $\stackrel{n}{n}$ & S̆ & : & $\begin{array}{l}\vec{\sigma} \\
\text { in }\end{array}$ & $\stackrel{n}{=}$ \\
\hline $\begin{array}{l}\text { Summer } \\
\text { (III) }\end{array}$ & $\hat{q}$ & $\stackrel{\circ}{\dot{q}}$ & $\stackrel{⿱ 亠 䒑 十}{\dot{\gamma}}$ & ڤn & $\stackrel{\infty}{\circ}$ & 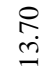 & 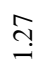 & $\stackrel{m}{\sim}$ & $\begin{array}{l}\text { B } \\
\stackrel{+}{+}\end{array}$ & $\stackrel{\circ}{\stackrel{+}{N}}$ \\
\hline Average & $\stackrel{\leftrightarrow}{\infty}$ & $\stackrel{r}{r}$ & $\stackrel{\partial}{\vec{q}}$ & $\underset{i}{\stackrel{d}{n}}$ & $\stackrel{m}{0}$ & $\hat{\sigma}$ & ্ָ & $\stackrel{\circ}{\infty}$ & $\stackrel{\text { I }}{m}$ & \\
\hline
\end{tabular}

In all groups of runs, the electric drive system of a car (BEV) is dominated, in which the combustion engine is turned on occasionally, which is reflected in mileage consumption of combustion engine. It should be noted that theoretically the range of tested car was $75 \mathrm{~km}$ on electric drive, hence the low mileage fuel consumption because most of the test drives were electric. However, the slight differences in the mileage consumption of fuel (Fig. 2a) do not correspond to the significant changes resulting from the mileage energy consumption (Fig. 2b).

The differences in mileage energy consumption are approximately $30 \%$ between the minimum and maximum values. It should be noted that the changes in average speed, distance and driving time have changed slightly. The difference between the average minimum and maximum speed was $4.5 \mathrm{~km} / \mathrm{h}$ and is related to improved weather conditions on the road. The average temperature changed from $5.1^{\circ} \mathrm{C}$ (winter period) to $24.0^{\circ} \mathrm{C}$ (summer period). A significant change in temperature changed the total ener- gy expenditure for a covering a distance of about $50 \mathrm{~km}$ (Fig. 3).

a)

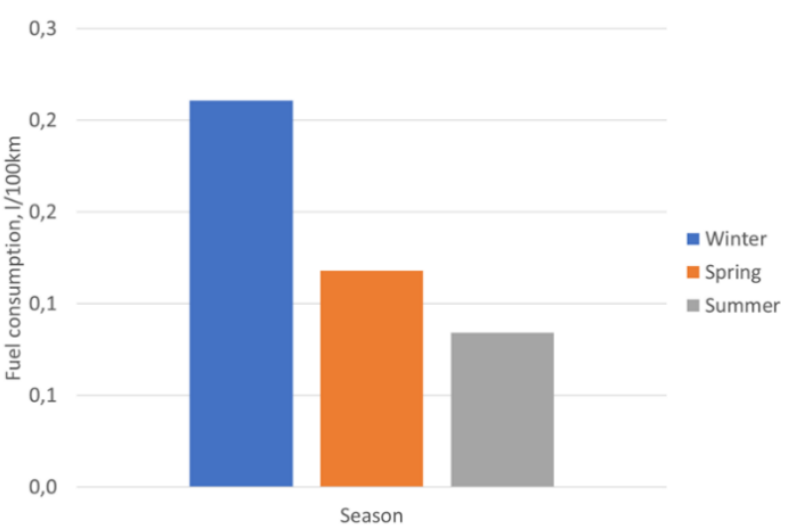

b)

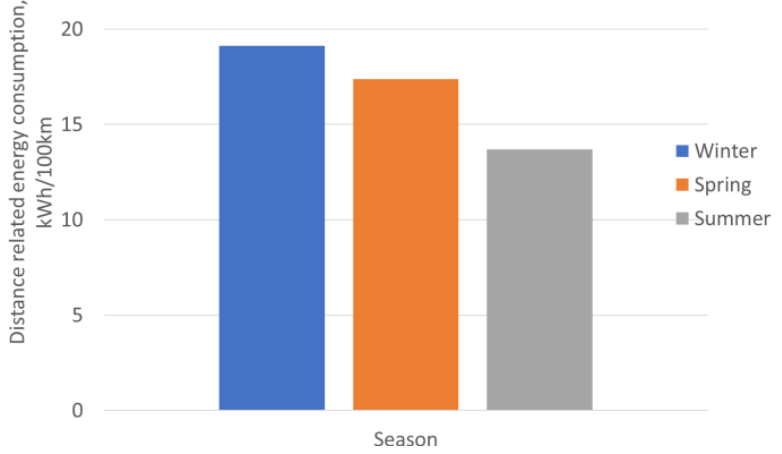

Fig. 2. The mileage consumption of energy carriers in relation to the season in which the measurements were carried out (for the distance traveled once)

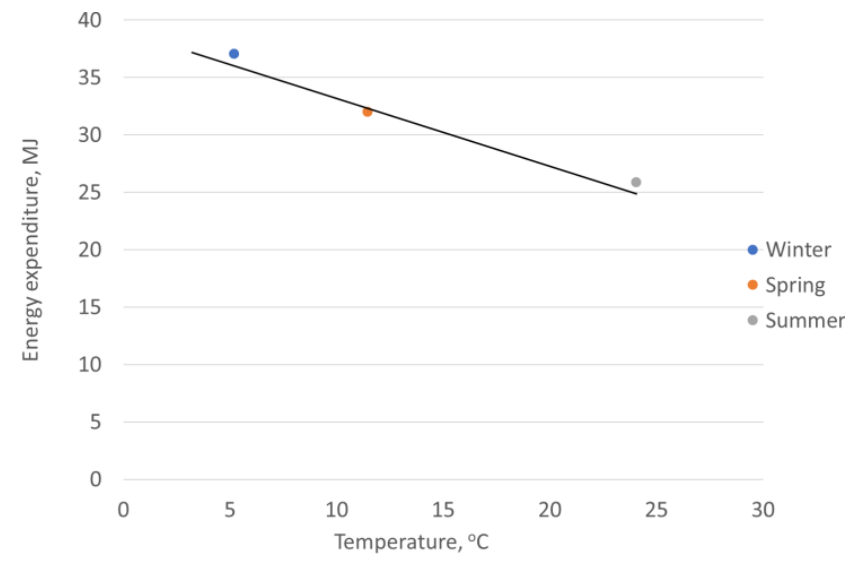

Fig. 3. Energy expenditure for a distance of $50 \mathrm{~km}$ in relation to the average temperature over a given season

Paying attention to values of energy expenditure, it can be stated that it depends on temperature, while the total cumulative energy expenditure of tested car over a distance of $12500 \mathrm{~km}$ in a given quarter increases in a linear manner and is characterized by a high coefficient of determination $\mathrm{R}^{2}$ (Fig. 4). 


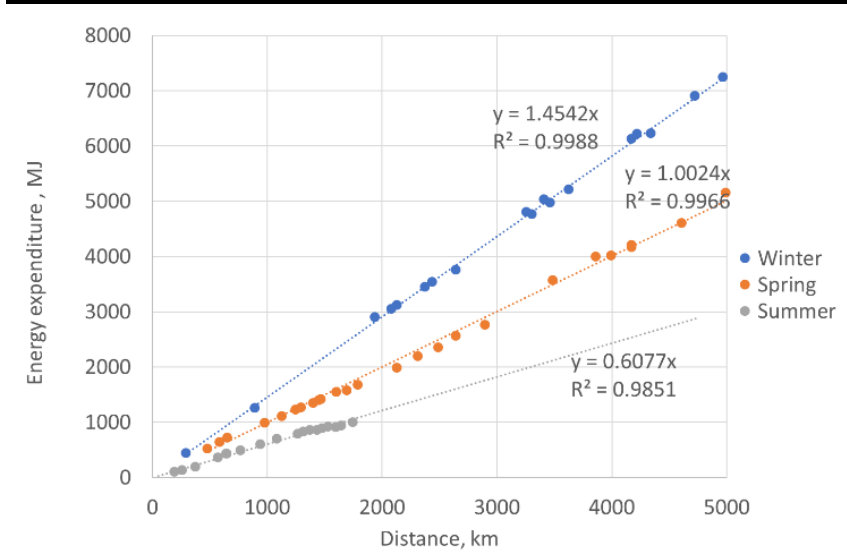

Fig. 4. The cumulative expenditure of converted energy (for a distance of approximately $50 \mathrm{~km}$ ) in relation to the total vehicle mileage during the period considered

The diagram shows the energy expenditure for the entire Plug-in Hybrid Electric Drive, where the increase in its expenditure is proportional to the mileage (approximation in Fig. 4). The greater the energy expenditure MJ, the greater the range in $\mathrm{km}$. For the course of these functions, the differential can be found and presented in the form of dependence (6):

$$
\frac{\Delta \mathrm{E}_{\mathrm{T}}}{\Delta \mathrm{L}}=\operatorname{tg} \alpha=\mathrm{Q}_{\mathrm{PHEV}}
$$

Thus, the slope of approximation line in Fig. 4 depends, on the one hand, on energy expenditure and on the other hand on road increment, which can be written directly as the quotient (6) describing the trigonometric function $\operatorname{tg} \alpha$, where the angle of this function is the angle of approximation line slope and presents the car's mileage energy consumption.

The mileage consumption of a car depends on distance traveled and its highest values are found in winter runs. The average instantaneous amount of energy expended in winter is $1.45 \mathrm{MJ} / \mathrm{km}$, and in summer $0.60 \mathrm{MJ} / \mathrm{km}$, and is more than twice as high. Moreover, in winter, after traveling a distance of $50 \mathrm{~km}$, the range of an electric car was very often $0 \mathrm{~km}$. In summer period, the range after driving 50 $\mathrm{km}$ is indicated about 22 to $25 \mathrm{~km}$, which is consistent with the declared range of electric drive (Table 2).

At the same time, there are also significant discrepancies in relation to individual types of propulsion, taking into account the average values. From this point of view, (Fig. 5) shows the total energy consumption in relation to the distance traveled $(50 \mathrm{~km}$ distance traveled at a time $)$ and divided by usage of individual drive units to drive the vehicle.

The greatest differentiation in energy expenditure can be observed for combustion engine, where the energy expenditure per kilometer of road traveled varies from 0.14 $\mathrm{MJ} / \mathrm{km}$ in summer to $0.93 \mathrm{MJ} / \mathrm{km}$ in winter (Fig. 5a). The fluctuations in energy expenditure for electric drive system are much smaller and range from 0.46 to $0.55 \mathrm{MJ} / \mathrm{km}$ and are much less dependent on temperature.

Referring to the mileage energy consumption of a car with the hybrid drive system in terms of the total vehicle mileage in each test, it is lower for mileage from groups II (spring) and III (summer) than that resulting from the
WLTP approval tests, amounting to $1.09 \mathrm{MJ} / \mathrm{km}$ for the test car. In winter, the energy expenditure is $40 \%$ higher than the homologation cycle. The lowest values are for runs in group III (summer), where the value of mileage energy consumption was $0.60 \mathrm{MJ} / \mathrm{km}$ (Fig. 4).
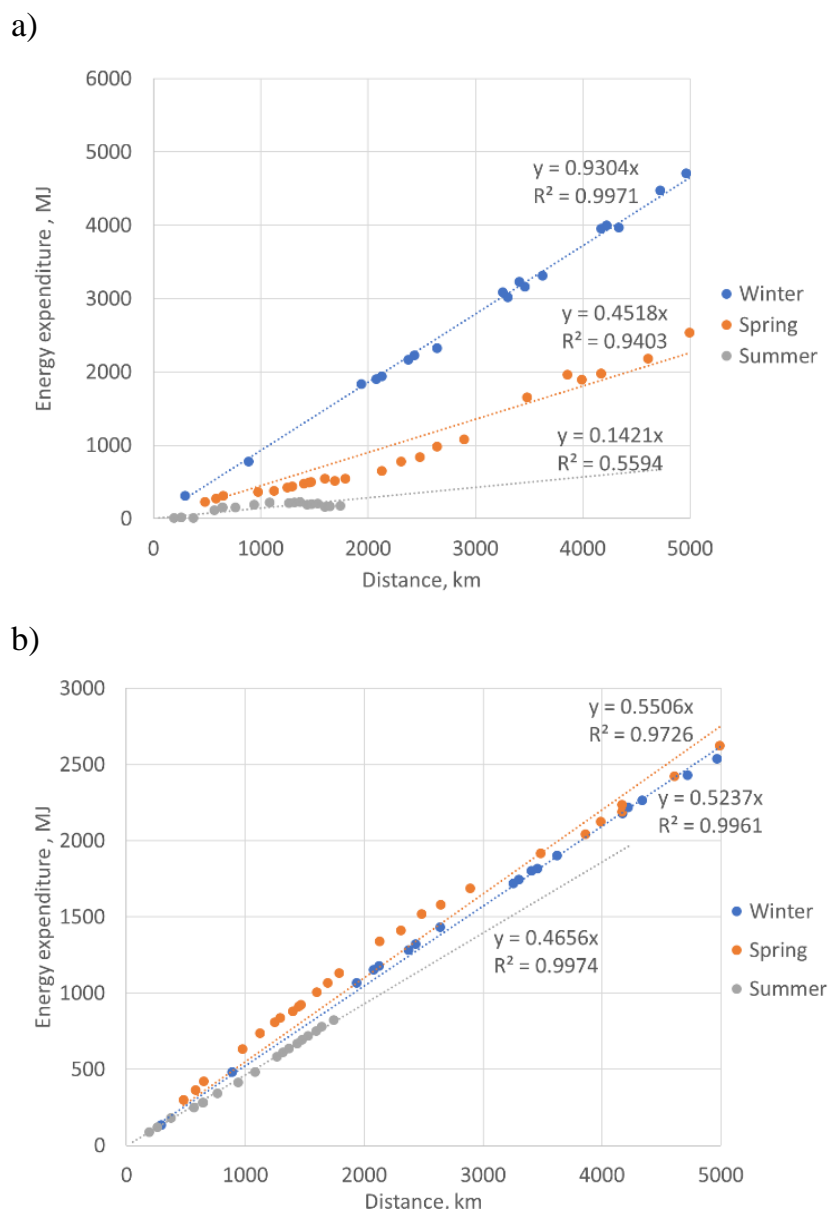

Fig. 5. Energy expenditure for distances of about $50 \mathrm{~km}$ in relation to the total mileage of the vehicle in the tested period, divided into individual drives: a) internal combustion engine, b) electric drive.

The presented values were related to results in the WLTP homologation cycle, however, it should be emphasized that only test drives performed at a distance close to the range resulting from the capacity of electric energy storage were analyzed. The implementation of longer test drives requires an increase in the capacity of electrical energy storage (batteries) to maintain the mileage consumption value below that obtained in the WLTP homologation tests.

During the research, attention was drawn to relation between the actual capacity of electric energy storage and ambient temperature. The problem of battery capacity reduction and the external temperature, described in the literature, was noticed, where at the temperature $-15^{\circ} \mathrm{C}$, the range of an electric car decreased to $21 \mathrm{~km}$ [9]. The range for electric drive declared in Table 2 allows for a distance of $75 \mathrm{~km}$, but at a temperature higher than $18^{\circ} \mathrm{C}$. After exceeding this distance, the driver has practically only the internal combustion engine (ICEV) with function of energy recovery in the deceleration process. For the test car, the average energy recovery is $25 \%$. 


\section{Summary}

The analysis of the car's mileage consumption for a Plug-in Hybrid Electric Drive in real operating conditions presented in the article shows a differentiated energy expenditure depending directly on the ambient temperature, but also on the type of drive system used. The presented calculations of energy expenditure based on unified data from real test drives in normal traffic conditions allow for the formulation of the following conclusions:

- the analysis of the car's mileage energy consumption in instantaneous and cumulative terms shows a significant increase in energy on the internal combustion engine side, which is structurally and mechanically complicated, but its advantage is the use of a simple energy storage device with high energy capacity. The electric drive unit is structurally and mechanically simple, while the electric energy reservoir is characterized by a complex structure, considerable weight, and limited capacity,

- the analysis of the car's mileage energy consumption, divided into individual drive units, shows an over 9-fold increase in its value depending on the temperature. For the electric drive unit in the TTW system, the changes are small,

- the analysis of ambient temperature influence on a passenger car range with a hybrid drive system causes a significant increase in the car's mileage energy consumption. And for test drives in the winter season with the ambient temperature $-15^{\circ} \mathrm{C}$, the real range of the during test car shortened to $21 \mathrm{~km}$ from the declared range of $75 \mathrm{~km}$.

The various 67 runs presented in the article in the period from winter to summer, differing in terms of traffic conditions, but carried out on the same distance and route, can be compared with the values recorded in the WLTP test. Higher values of the car's mileage energy consumption were recorded for winter conditions, where the average temperature was $5.2^{\circ} \mathrm{C}$. In the remaining periods, the average value of vehicle's mileage consumption is below the value obtained for the WLTP homologation test. At the same time, the converted value of carbon dioxide $\mathrm{CO}_{2}$ emissions for these runs meets the requirements of the current (2021) Euro 6 (AP) emission standard of $95 \mathrm{~g} / \mathrm{km}$.

\section{Nomenclature}

$\bar{a} \quad$ average acceleration $\left[\mathrm{m} / \mathrm{s}^{2}\right]$

AT Automatic Transmission

BEV Battery Electric Vehicle

$\mathrm{E}_{\mathrm{M}} \quad$ motion energy consumption $[\mathrm{J}]$

EM Electric Motor

$\mathrm{E}_{\mathrm{T}} \quad$ energy produced from burned fuel [J]

$\mathrm{E}_{\mathrm{Te}} \quad$ total energy for electric drive unit [J]

$\mathrm{E}_{\mathrm{Tf}}$ total energy for combustion engine drive unit [J]

EV Electric Vehicle

VFC Vehicle Fuel Consumption [kg/s]

F-DCT Front-Double Clutch Transmission

HEV Hybrid Electric Vehicle

ICE Internal Combustion Engine

ICEV Internal Combustion Engine Vehicle

$\mathrm{L} \quad$ road length [m]

MT Manual Transmission

$\mathrm{P} \quad$ electrical power [W]

PHEV Plug-in Hybrid Electric Vehicle
Q

$\mathrm{Q}_{\mathrm{f}} \quad$ mileage fuel consumption $\left[\mathrm{dm}^{3} / 100 \mathrm{~km}\right]$

$\mathrm{Q}_{\mathrm{e}} \quad$ mileage electric energy consumption $[\mathrm{kWh} / 100 \mathrm{~km}]$

$\mathrm{Q}_{\mathrm{Tf}}$ energy consumption as energy contained in the fuel $[\mathrm{MJ}]$

$\mathrm{Q}_{\mathrm{Te}} \quad$ energy consumptions of the electric drive unit [MJ]

$\mathrm{Q}_{\mathrm{T} \_ \text {PHEV }}$ energy consumption of PHEV [MJ]

SOC State of Charge

$\mathrm{t}_{\mathrm{s}, \mathrm{e}} \quad$ start and end time of energy calculation [s]

TTW Tank to Wheels

$\overline{\mathrm{V}} \quad$ average speed $[\mathrm{m} / \mathrm{s}]$

WLTP The Worldwide Harmonized Light Vehicles Test Procedure

$\mathrm{W}_{\mathrm{O}} \quad$ calorific fuel value $[\mathrm{J} / \mathrm{kg}]$

$\Delta \mathrm{E}_{\mathrm{D}} \quad$ energy losses of internal combustion engine $[\mathrm{J}]$

$\Delta \mathrm{E}_{\mathrm{E}} \quad$ energy losses of electric drive unit [J]

$\Delta \mathrm{E}_{\mathrm{L}} \quad$ loss of energy supplied to the drive system without being transferred to the drive wheels [J]

\section{Bibliography}

[1] ÅHMAN, M. Primary energy efficiency of alternative powertrains in vehicles. Energy. 2001, 26(11), 973-989. https://doi.org/10.1016/S0360-5442(01)00049-4

[2] BARTH, M., BORIBOONSOMSIN, K. Energy and emissions impacts of a freeway-based dynamic eco-driving system. Transportation Research Part D: Transport and Environment. 2009, 14(6), 400-410.

https://doi.org/10.1016/j.trd.2009.01.004

[3] BECKER, T., SIDHU, I., TENDERICH, B. Electric vehicles in the United States: a new model with forecasts to 2030. Technical Brief. University of California. Center for Entrepreneurship and Technology. Berkeley 2009.

[4] BIENIEK, A., GRABA, M., HENNEK, K. et al. Analysis of fuel consumption of a spark ignition engine in the conditions of a variable load. MATEC Web of Conferences. 2017, 118. https://doi.org/10.1051/matecconf/201711800036
[5] BOKARE, P.S., MAURYA, A.K. Acceleration-deceleration behaviour of various vehicle types. Transportation Research Procedia. 2017, 25, 4733-4749.

https://doi.org/10.1016/j.trpro.2017.05.486

[6] CHŁOPEK, Z. Research on energy consumption by an electrically driven automotive vehicle in simulated urban conditions. Eksploatacja i Niezawodnosc - Maintenance and Reliability. 2013, 15(1), 75-82.

[7] ARENA, F., SPERA, D., LAGUARDIA F. What's in the future for fuel cell vehicles? 2017.

https://www.adlittle.com/en/insights/viewpoints/what\%E2\% 80\%99s-future-fuel-cell-vehicles

[8] DELLOITLE. Fuelling the future mobility - hydrogen and fuel cell solutions for transportation. 2019.

https://www2.deloitte.com/content/dam/Deloitte/cn/Docume nts/finance/deloitte-cn-fueling-the-future-of-mobility-en200101.pdf 
[9] GRABA, M., MAMALA, J., BIENIEK, A. et al. Impact of the acceleration intensity of a passenger car in a road test on energy consumption. Energy. 2021, 226, 120429. https://doi.org/10.1016/j.energy.2021.120429

[10] International Energy Agency. Energy Technology Perspectives 2017 - Executive Summary. 2017. https://doi.org/10.1787/energy_tech-2014-en

[11] KE, W., ZHANG, S., HE, X. et al. Well-to-wheels energy consumption and emissions of electric vehicles: Mid-term implications from real-world features and air pollution control progress. Applied Energy. 2017, 188, 367-377. https://doi.org/10.1016/j.apenergy.2016.12.011

[12] KROPIWNICKI, J., FURMANEK, M. Analysis of the regenerative braking process for the urban traffic conditions. Combustion Engines. 2019, 178(3), 203-207. https://doi.org/10.19206/CE-2019-335

[13] KROPIWNICKI, J. A unified approach to the analysis of electric energy and fuel consumption of cars in city traffic. Energy. 2019, 182, 1045-1057. https://doi.org/10.1016/j.energy.2019.06.114

[14] LIMBLICI, C. Investigation of engine concepts with regard to their potential to meet the Euro 7 emission standard using 1D-CFD software. Politecnico di Torino. Master Thesis. 2020. https://webthesis.biblio.polito.it/16275/

[15] MAMALA, J., GRABA, M., PRAŻNOWSKI, K. et al. Control of the effective pressure in the cylinder of a sparkignition engine by electromagnetic valve actuator. $S A E$ Technical Papers 2019-01-1201. 2019. https://doi.org/10.4271/2019-01-1201

[16] MAMALA, J., ŚMIEJA, M., PRAŻNOWSKI, K. Analysis of the total unit energy consumption of a car with a hybrid drive system in real operating conditions. Energies. 2021, 14(13), 3966. https://doi.org/10.3390/en14133966

[17] ORECCHINI, F., SANTIANGELI, A., ZUCCARI, F. et al. Energy consumption of a last generation full hybrid vehicle compared with a conventional vehicle in real drive conditions. Energy Procedia. 2018, 148, 289-296.

https://doi.org/10.1016/j.egypro.2018.08.080

[18] PIELECHA, I., CIEŚLIK, W., SZAŁEK, A. Operation of electric hybrid drive systems in varied driving conditions. Eksploatacja $i$ Niezawodnosc - Maintenance and Reliability. 2018, 20(1), 16-23.

https://doi.org/10.17531/ein.2018.1.3

\footnotetext{
Andrzej Bieniek, DEng. - Faculty of Mechanical Engineering, Opole University of Technology. e-mail:a.bieniek@po.edu.pl
}

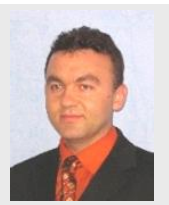

Mariusz Graba, DEng. - Faculty of Mechanical Engineering, Opole University of Technology. e-mail:m.graba@po.edu.pl
[19] PIELECHA, I., PIELECHA, J. Simulation analysis of electric vehicles energy consumption in driving tests. Eksploatacja i Niezawodnosc - Maintenance and Reliability. 2020, 22(1), 130-137.

https://doi.org/10.17531/ein.2020.1.15

[20] PITANUWAT, S., SRIPAKAGORN, A. An investigation of fuel economy potential of hybrid vehicles under real-world driving conditions in Bangkok. Energy Procedia. 2015, 79, 1046-1053. https://doi.org/10.1016/j.egypro.2015.11.607

[21] QIU, S., QIU, L., QIAN, L. et al. Hierarchical energy management control strategies for connected hybrid electric vehicles considering efficiencies feedback. Simulation Modelling Practice and Theory. 2019, 90, 1-15. https://doi.org/10.1016/j.simpat.2018.10.008

[22] SHARER, P., LEYDIER, R., ROUSSEAU, A. Impact of drive cycle aggressiveness and speed on HEVs fuel consumption sensitivity. SAE Technical Papers 2007-01-0281. 2007. https://doi.org/10.4271/2007-01-0281

[23] THOMAS, J., HUFF, S., WEST, B. et al. Fuel consumption sensitivity of conventional and hybrid electric light-duty gasoline vehicles to driving style. SAE International Journal of Fuels and Lubricants. 2017, 10(3). https://doi.org/10.4271/2017-01-9379

[24] WANG, H., ZHANG, X., OUYANG, M. Energy consumption of electric vehicles based on real-world driving patterns: A case study of Beijing. Applied Energy. 2015, 157, 710719.

https://doi.org/10.1016/j.apenergy.2015.05.057

[25] WANG, Z., ZHAO, Z., WANG, D. et al. Impact of pilot diesel ignition mode on combustion and emissions characteristics of a diesel/natural gas dual fuel heavy-duty engine. Fuel. 2016, 167, 248-256. https://doi.org/10.1016/j.fuel.2015.11.077

[26] YEO, H., HWANG, S., KIM, H. Regenerative braking algorithm for a hybrid electric vehicle with CVT ratio control. Proceedings of the Institution of Mechanical Engineers, Part D: Journal of Automobile Engineering. 2006, 220(11), 1589-1600. https://doi.org/10.1243/09544070JAUTO304

[27] Mercedes-Benz A250e homologation certificate. 2020.

[28] Mercedes me media. https://www.mercedesbenz.pl/pasengercars mercedes-benz-cars/mercedes-me

Prof. Jarosław Mamala, DSc., DEng. - Faculty of Mechanical Engineering, Opole University of Technology.

e-mail:j.mamala@po.edu.pl

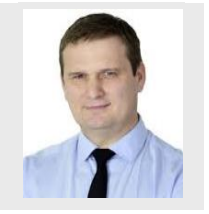

Krzysztof Prażnowski, DEng.- Faculty of Mechanical Engineering, Opole University of Technology. e-mail: k.praznowski@po.edu.pl

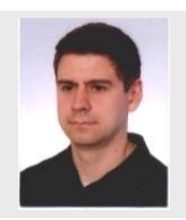

Krystian Hennek, MEng. - PhD student in the Faculty of Mechanical Engineering, Opole University of Technology.

e-mail:k.hennek@po.edu.pl

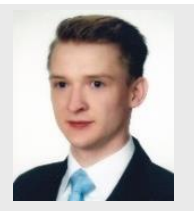

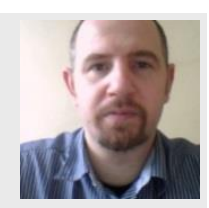

